\title{
Pengaruh Model Pembelajaran Kooperatif Tipe Numbered Heads Together (NHT) Terhadap Hasil Belajar Peserta Didik pada Mata Pelajaran Teknik Pemograman Mikroprosesor dan Mikrokontroler Kelas X Jurusan Mekatronika SMKN 56 Jakarta
}

\author{
Ainil Husna ${ }^{1}$, Mufti Ma 'sum ${ }^{2}$, Jusuf Bintoro ${ }^{3}$ \\ ${ }^{1}$ Mahasiswa Prodi Pendidikan Teknik Elektronika, Fakultas Teknik - UNJ \\ ${ }^{2}$ Dosen Prodi Pendidikan Teknik Elektronika, Fakultas Teknik - UNJ \\ ${ }^{3}$ Dosen Prodi Pendidikan Teknik Elektronika, Fakultas Teknik - UNJ
}

\begin{abstract}
Abstrak Penelitian ini bertujuan untuk mengetahui pengaruh model pembelajaran kooperatif tipe Numbered Heads Together terhadap hasil belajar peserta didik pada mata pelajaran teknik pemograman mikroprosesor dan mikrokontroler kelas X jurusan mekatronika SMKN 56 Jakarta. Penelitian menggunakan metode penelitian Eksperimen dengan menggunakan metode Preexperimental Design dengan design penelitian "One Group Pretest-Posttest Design". Populasi penelitian dalam penelitian ini adalah seluruh peserta didik kelas X Jurusan Mekatronika. Teknik pengambilan sampel yang digunakan adalah sampling jenuh, dimana yang menjadi sampelnya adalah seluruh peserta didik kelas $\mathrm{X}$ Jurusan Mekatronika sebagai kelas eksperimen yang belajar menggunakan model pembelajaran kooperatif tipe Numbered Heads Together. Instrumen penelitian berupa tes pilihan ganda sebanyak 30 butir soal. Pengujian hipotesis menggunakan rumus uji $\mathrm{t}$ dan diperoleh hasil pengujian $h>$ yaitu 29,03 > 2,03452 berarti H1 diterima atau adanya pengaruh model pembelajaran kooperatif tipe Numbered Heads Together (NHT) terhadap hasil belajar peserta didik kelas X Mekatronika pada mata pelajaran Teknik Pemograman Mikroprosessor dan Mikrokontroler.
\end{abstract}

Kata Kunci: Model pembelajaran kooperatif tipe Numbered Heads Together (NHT), Hasil Belajar Teknik Pemograman Mikroprosessor dan Mikrokontroler. 


\section{Pendahuluan}

Masalah saat ini yang paling diprioritaskan oleh pemerintah Indonesia adalah masalah pendidikan. Pendidikan di Indonesia merupakan suatu aspek yang sangat berpengaruh bagi sumber daya manusianya. Bukti jika pendidikan di Indonesia sangat diprioritaskan atau diperhatikan oleh pemerintah adalah dari wajibnya peserta didik sekolah 12 tahun (SD, SMP, SMA/SMK), banyaknya beasiswa yang diberikan kepada peserta didik yang kurang mampu, serta dana anggaran untuk pendidikan di APBN sebesar 10\%. Pendidikan itu bisa kita dapatkan dimana saja. Bisa di lingkungan keluarga atau disebut dengan proses belajar mengajar informal. Bisa juga di sekolah atau disebut dengan proses belajar mengajar formal. Proses pendidikan dalam lingkungan sekolah harus melalui perencanaan yang tersusun secara sistematis. Selama ini pendidikan yang dilakukan masih banyak yang berpusat pada guru atau masih banyak menggunakan metode ceramah saja. Guru aktif menjelaskan pengetahuan dari awal sampai tuntas, sedangkan peserta didik hanya mendengarkan dan mencatat apa yang dikatakan oleh guru. Guru hendaknya dapat menciptakan suasana pendidikan yang bermakna dan menyenangkan bagi peserta didik. Penggunaan metode yang hanya berpusat pada guru membuat peserta didik menjadi pasif dan berpengaruh kepada hasil belajarnya. Karena jika model atau metode yang digunakan guru tersebut menarik perhatian peserta didik dan menimbulkan minat mereka dalam memahami materi pembelajaran, maka tingkat keberhasilan belajar berkemungkinan tinggi. Sebaliknya, jika model atau metode yang digunakan guru tidak menarik, dan peserta didik tidak berusaha untuk memahami materi pembelajaran, maka tingkat keberhasilannya akan rendah. Sekolah Menengah Kejuruan (SMK) adalah pendidikan formal yang mempunyai tujuan untuk mempersiapkan peserta didiknya untuk dapat terjun langsung ke dunia industri. Teknik Pemograman Mikroprosesor dan Mikrokontroler merupakan salah satu mata pelajaran di SMK khususnya di jurusan Mekatronika. Dimana mata pelajaran ini membahas tentang control statement dan perulangan. Berdasarkan wawancara dengan guru mata pelajaran TPMM, peserta didik hanya monoton mendengarkan guru menjelaskan pelejaran atau yang biasa disebut dengan metode ceramah, tanpa ikut aktif dalam proses belajar mengajar. Sementara pada materi ini peserta didik diminta aktif untuk ikut berpartisipasi baik secara mental dan fisik sehingga keberhasilan dari proses tersebut sangatlah rendah. Terbukti dari nilai dari hasil UTS peserta didik kelas X Mekatronika yang rendah, sebagaimana yang dijelaskan pada Tabel I berikut ini.

Tabel 1.1 Data Persentase Nilai UTS pada Mata Pelajaran TPMM

\begin{tabular}{|c|c|c|c|c|c|c|}
\hline Kelas & KKM & $\begin{array}{c}\text { Jumlah } \\
\text { Siswa }\end{array}$ & $\begin{array}{c}\text { Jumlah } \\
\text { Siswa } \\
\text { Tuntas }\end{array}$ & $\begin{array}{c}\text { Jumlah } \\
\text { Siswa } \\
\text { Tidak } \\
\text { Tuntas }\end{array}$ & $\begin{array}{c}\text { Persentase } \\
\text { Ketuntasan }\end{array}$ & $\begin{array}{c}\text { Persentase } \\
\text { Ketidaktuntasan }\end{array}$ \\
\hline $\begin{array}{c}\mathrm{X} \\
\text { Mekatronika }\end{array}$ & $\geq 80$ & 34 & 12 & 22 & $34 \%$ & $66 \%$ \\
\hline
\end{tabular}

Berdasarkan kondisi di atas, untuk meningkatkan hasil belajar peserta didik, peneliti mengajukan penelitian terhadap keterlibatan peserta didik secara aktif dan berpartisipasi dalam proses pembelajaran menggunakan model pembelajaran. Salah satunya yaitu menggunakan model pembelajaran kooperatif (Cooperative Learning). Model pembelajaran kooperatif ini merupakan model pembelajaran yang menekankan aktivitas kolaboratif peserta didik dalam belajar yang berbentuk kelompok, mempelajari materi pembelajaran, dan memecahkan masalah secara kolektif. Maka dari itu, peneliti menerapkan model pembelajaran tipe NHT (Numbered Head Together).Dari uraian di atas, peneliti ingin mengetahui pengaruh penggunaan model pembelajaran kooperatif tipe numbered head together pada mata pelajaran di jurusan mekatronika, oleh sebab itu perlu dilakukan penelitian mengenai "Pengaruh Model Pembelajaran Kooperatif tipe NHT (Numbered 
Head Together) Terhadap Hasil Belajar Peserta didik pada Mata Pelajaran Teknik Pemograman Mikroprosesor Dan Mikrokontroler Kelas X Mekatronika SMKN 56 Jakarta”.

\section{Metode}

Pada penelitian ini, peneliti menggunakan jenis penelitian kuantitatif. Untuk mendapatkan data dari penelitian kuantitatif ini, maka peneliti menggunakan metode penelitian Preexperimental Design tipe One Group Pre-test dan Post-test Design. Dimana bentuk desain penelitian ini akan dijelaskan pada rumus berikut:

$$
\begin{aligned}
& O_{1} \underset{x}{\longrightarrow} O_{2} \\
\text { O1 } & : \text { Pre-test } \\
\text { O2 } & : \text { Post-test } \\
\mathrm{X} & : \text { Perlakuan (model pembelajaran kooperatif tipe NHT }
\end{aligned}
$$

Penelitian ini menggunakan 2 variabel, variabel terikat adalah hasil belajar peserta didik yang diambil dari hasil pre-test dan post-test pada materi control statement dan perulangan dan variabel bebas adalah model pembelajaran kooperatif tipe NHT (Numbered Heads Together). Uji validitas yang digunakan peneliti adalah korelasi point biserial (rpbi) dan untuk uji realibilitasnya adalag KR-20. Uji normalitas data menggunakan uji chi kuadrat dengan taraf signifikasi 5\%. Sedangkan untuk uji hipotesis menggunakan uji t dependent dengan taraf signifikasi $5 \%$.

\section{Hasil}

Pada penelitian ini, peneliti memperoleh data penelitian dari serangkaian tes yang diberikan kepada kelas eksperimen. Tes tersebut dilakukan sebanyak dua kali yaitu tes awal (pretest) dan tes akhir (posttest). Penelitian juga menggunakan model pembelajaran kooperatif tipe Numbered Heads Together (NHT) dalam mengambil data penelitian. Langkah pertama yang dilakukan oleh peneliti dalam mengambil data penelitian adalah melakuka tes awal (pretest) pada peserta didik dalam kelas eksperimen mengenai materi yang terdapat pada mata pelajaran Teknik Pemograman Mikroprosessor dan Mikrokontroler. Langkah selanjutnya yaitu memberikan perlakuan kepada peserta didik dengan menggunakan model pembelajaran kooperatif tipe Numbered Heads Together (NHT) yang diberikan selama 4 kali pertemuan, dimana 1 kali pertemuan sama dengan 4 jam pelajaran. Setelah seleseasi memberikan perlakuan, peneliti akan memberikan tes akhir (posttest) kepada peserta didik. Selanjutnya data hasil penelitian ini dikelompokkan dari hasil pretest dan posttest pada mata pelajaran Teknik Pemograman Mikroprosessor dan Mikrokontroler ke dalam bentuk tabel distribusi frekuensi dan histogram.

Tabel 3.1 Rekapitulasi Data Hasil Pretest dan Posttest

\begin{tabular}{|c|cc|}
\hline \multicolumn{2}{|c|}{ Statistik } & \multicolumn{3}{|c|}{ TPMM } \\
\hline Nilai Terendah & Pretest & Posttest \\
Nilai Tertinggi & 60 & 70 \\
Jangkauan & 27 & 90 \\
Interval & 5 & 20 \\
Mean & 52,5 & 4 \\
Median & 53,65 & 81,97 \\
& & 82,5 \\
\hline
\end{tabular}




\subsection{Data Hasil Pretest}

Pada penelitian ini, data pretest diperoleh dari peserta didik kelas eksperimen yang berjumlah 34 peserta didik. Dan dari data tersebut didapatkan nilai terendah yaitu 33 dan nilai tertinggi yaitu 60 dengan varians 36,74 dan standar deviasi 6,06. Dari hasil deskripsi data tersebut dapat dibuat ke dalam tabel berikut ini.

Tabel 3.2 Distribusi Frekuensi Hasil Pretest

\begin{tabular}{c|c|c|c|c|c|}
\hline Kelas & Nilai & $\mathrm{f}$ & $\mathrm{fk}$ & $\mathrm{Xi}$ & $\begin{array}{c}\text { Frek } \\
\%\end{array}$ \\
\hline 1 & $33-37$ & 1 & 1 & 35 & $2,91 \%$ \\
2 & $38-42$ & 0 & 1 & 40 & $0 \%$ \\
3 & $43-47$ & 7 & 8 & 45 & $20,6 \%$ \\
4 & $48-52$ & 6 & 14 & 50 & $17,6 \%$ \\
\hline 5 & $53-57$ & 13 & 27 & 55 & $38,2 \%$ \\
\hline 6 & $58-62$ & 7 & 34 & 60 & $20,6 \%$ \\
\multicolumn{2}{|c|}{ Jumlah } & 34 & & & $100 \%$ \\
\multicolumn{2}{l|}{ Rata-rata } & & & 52,5 & \\
\end{tabular}

Berdasarkan tabel distribusi frekuensi hasil pretest, didapatkan nilai rata-ratanya adalah 52,5. Sedangkan median dan modusnya adalah 53,65 dan 54,8 pada interval ke-5 (53-57) dengan frekuensi sebanyak 13. Selain itu, diketahui juga bahwa hasil pretest peserta didik pada mata pelajaran Teknik Pemograman Mikroprosessor dan Mikrokontroler didistribusikan menjadi 6 kelas dengan frekuensi rendah terdapat pada interval ke-2 (38-42) sebanyak 0 dan frekuensi tertinggi terdapat pada interval ke-5 (53-57) sebanyak 13.

\subsection{Data Hasil Posttest}

Data posttest diperoleh dari peserta didik kelas eksperimen setelah diberikannya perlakuan oleh peneliti dengan menggunakan model pembelajaran kooperatif tipe Numbered Heads Together (NHT). Dan dari data tersebut didapatkan nilai terendah yaitu 70 dan nilai tertinggi yaitu 90 dengan varians 48,50 dan standar deviasi 6,96. Dari hasil deskripsi data tersebut dapat dibuat ke dalam tabel berikut ini.

Tabel 3.3 Distribusi Frekuensi Hasil Posttest

\begin{tabular}{|c|c|c|c|c|c|}
\hline Kelas & Nilai & $\mathrm{f}$ & $\mathrm{Fk}$ & $\mathrm{Xi}$ & $\begin{array}{r}\text { Frek } \\
\%\end{array}$ \\
\hline 1 & $70-73$ & 6 & 6 & 71,5 & $17,6 \%$ \\
\hline 2 & 74-77 & 4 & 10 & 75,5 & $11,8 \%$ \\
\hline 3 & $78-81$ & 6 & 16 & 79,5 & $17,6 \%$ \\
\hline 4 & $82-85$ & 4 & 20 & 83,5 & $11,8 \%$ \\
\hline 5 & $86-89$ & 4 & 29 & 87,5 & $26,5 \%$ \\
\hline 6 & $90-93$ & 5 & 34 & & \\
\hline \multicolumn{2}{|c|}{$\begin{array}{l}\text { jumlah } \\
\text { Rata-rata }\end{array}$} & 34 & & 81,97 & $100 \%$ \\
\hline
\end{tabular}

Berdasarkan uraian hasil analisis deskripsi data pretest dan data posttest yang diperlukan untuk mengetahui pengaruh model pembelajaran tipe Numbered Heads Together (NHT) terhadap hasil belajar peserta didik pada mata pelajaran Teknik Pemograman Mikroprosessor dan Mikrokontroler, maka dilakukan perbandingan hasil belajar yang diperoleh dari kedua hasil pengukuran yang telah dijelaskan sebelumnya. Berikut ini disajikan bentuk tabel perbandingan hasil belajar berupa nilai rata-rata antara hasil belajar pretest dan hasil belajar posttest pada tabel dibawah ini 
Tabel 3.4 Peningkatan Hasil Belajar Pretest dan Posttest

\begin{tabular}{cccc}
\multirow{2}{*}{ Kelas } & Mean & Mean & \\
& & & Peningkatan \\
Eksperimen & 52,5 & 81,97 & 29,47
\end{tabular}

Dari uraian tabel diatas, dapat dilihat adanya peningkatan hasil belajar dari hasil belajar peserta didik sebelum diberikan perlakuan (pretest) dan sesudah diberikan perlakuan (posttest) pada mata pelajaran Teknik Pemograman Mikroprosessor dan Mikrokontroler di kelas X Mekatronika.

\subsection{Histogram Hasil Pretest dan Posttest}

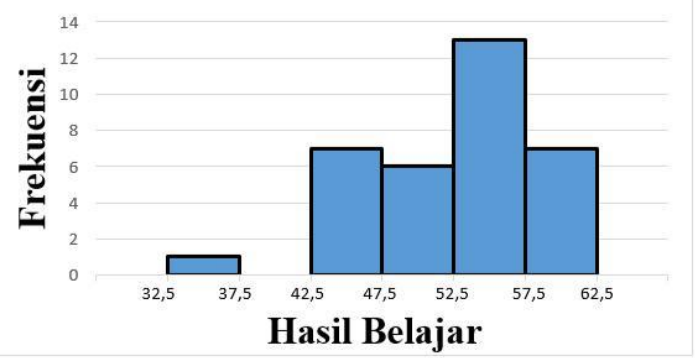

Gambar 3.1 Histogram Hasil Pretest

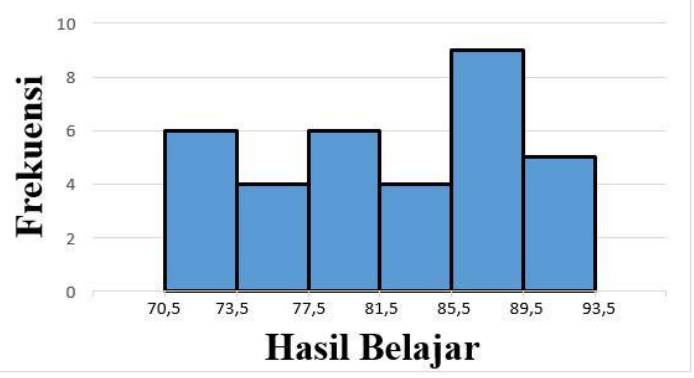

Gambar 3.2 Histogram Hasil Posttest

\subsection{Uji Normalitas Pretest Kelas Eksperimen}

Dari hasil data perhitungan pretest kelas eksperimen pada mata pelajaran Teknik Pemograman Mikroprosessor dan Mikrokontroler diperoleh hasil perhitungan uji normalitas dengan nilai $2 h$ yaitu 7,8755. Sementara itu nilai 2 yang diperoleh dari perhitungan $\mathrm{dk}=\mathrm{n}-1$, dimana $\mathrm{n}$ adalah banyaknya kelas dalam data kelompok pretest dengan taraf signifikan 0,05 pada tabel chi kuadrat didapatkan nilai 2 yaitu 11,070. Berdasarkan perhitungan diatas dapat disimpulkan bahwa yaitu 7,8755 $<11,070$, maka H0 diterima atau data berasal dari populasi berdistribusi normal dan dapat dilihat pada tabel berikut.

Tabel 3.5 Hasil Uji Normalitas Pretest

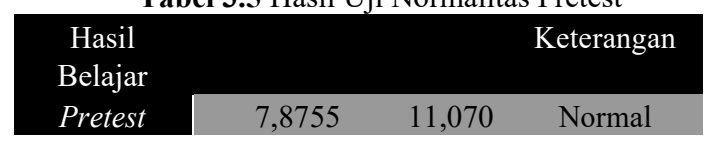

Berdasarkan tabel diatas, dapat disimpulkan bahwa hasil pretest kelas eksperimen pada mata pelajaran Teknik Pemograman Mikroprosessor dan Mikrokontroler berdistribusi normal. 


\subsection{Uji Normalitas Posttest Kelas Eksperimen Dari hasil data perhitungan posttest kelas}

eksperimen pada mata pelajaran Teknik Pemograman Mikroprosessor dan Mikrokontroler diperoleh hasil perhitungan uji normalitas dengan nilai $2 h$ yaitu 10,0539 . Sementara itu nilai 2 yang diperoleh dari perhitungan $\mathrm{dk}=\mathrm{n}-1$, dimana $\mathrm{n}$ adalah banyaknya kelas dalam data kelompok posttest dengan taraf signifikan 0,05 pada tabel chi kuadrat didapatkan nilai 2 yaitu 11,070. Berdasarkan perhitungan diatas dapat disimpulkan bahwa $2 h<2$ yaitu $10,0539<11,070$, maka $\mathrm{H} 0$ diterima atau data berasal dari populasi berdistribusi normal dan dapat dilihat pada tabel berikut.

Tabel 3.6 Hasil Uji Normalitas Posttest

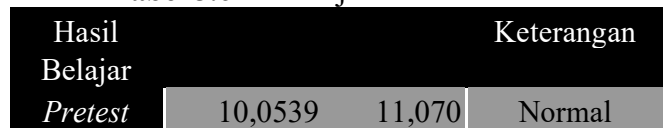

Berdasarkan tabel diatas, dapat disimpulkan bahwa hasil posttest kelas eksperimen pada mata pelajaran Teknik Pemograman Mikroprosessor dan Mikrokontroler berdistribusi normal.

\section{6 pengujian hipotesis}

Setelah melakukan beberapa pengujian data hasil pretest dan posttest yang dilakukan oleh peneliti,, maka langkah selanjutnya yang akan dilakukan oleh peneliti adalah pengujian hipotesis menggunakan uji-t (dependent t-test) dengan kriteria pengujian sebagai berikut :

Jika $h \leq$ maka H0 diterima

Jika $h>$ maka H1 diterima

Berdasarkan hasil perhitungan menggunakan rumus uji t diperoleh $h$ yaitu 29,03, sedangkan hasil perhitungan menggunakan tabel signifikasi 0,05 diperoleh yaitu 2,03452. Maka dapat disimpulkan bahwa $h>$ yaitu 29,03 > 2,03452 berarti H1 diterima atau adanya pengaruh positif model pembelajaran kooperatif tipe Numbered Heads Together (NHT) terhadap hasil belajar peserta didik kelas X Mekatronika pada mata pelajaran Teknik Pemograman Mikroprosessor dan Mikrokontroler.

\section{7 pembahasan}

Berdasarkan hasil penelitian yang telah dilakukan menggunakan perlakuan yang menerapkan model pembelajaran kooperatif tipe Numbered Heads Togehther pada kelas X Mekatronika SMKN 56 Jakarta, diperoleh nilai terendah pretest adalah 33 dan nilai tertinggi pretest adalah 60 dengan nilai rata-ratanya adalah 52,5. Sedangan nilai terendah posttest adalah 70 dan nilai tertinggi posttest adalah 90 dengan nilai rataratanya adalah 81,97. Dan didapatkan hasil peningkatan hasil belajar dari hasil pretest dan posttest sebesar 29,47. Selanjutnya data tersebut dilakukan uji persyaratan analisis data dengan menggunakan uji normalitas Chi Kuadrat yang memperoleh hasil bahwa kedua data tersebut baik data hasil pretest maupun data hasil posttest berdistribusi normal. Langkah yang akan dilakukan peneliti setelah menguji normlitas data adalah pengujian hipotesis. Peneliti menggunakan rumus uji t dengan taraf signfikasi 0,05 dalam pengujian hipotesis dan diperoleh hasil pengujian $h>$ yaitu $29,03>2,03452$ berarti $\mathrm{H} 1$ diterima atau adanya pengaruh positif model pembelajaran kooperatif tipe Numbered Heads Together (NHT) terhadap hasil belajar peserta didik kelas X Mekatronika pada mata pelajaran Teknik Pemograman Mikroprosessor dan Mikrokontroler.

\section{Kesimpulan}

Berdasarkan hasil penelitian yang telah dilakukan, dapat disimpulkan bahwa penggunaan model pembelajaran kooperatif tipe Numbered Heads Together (NHT) berpengaruh positif terhadap hasil belajar peserta didik pada mata pelajaran Teknik Pemograman Mikroprosessor dan Mikrokontroler kelas X Jurusan Mekatronika di SMKN 56 Jakarta. 
Terbukti dari pengujian hipotesis dan diperoleh hasil pengujian $h>$ yaitu 29,03 $>2,03452$ berarti H1 diterima.

\section{DATAR PUSTAKA}

1. Husna, Ainil. (2019). Pengaruh Model Pembelajaran Kooperatif Tipe Numbered Heads Together (NHT) terhadap Hasil Belajar Peserta Didik pada Mata Pelajaran TPMM Kelas X Jurusan Mekatronika SMKN 56 Jakarta. Jakarta: Universitas Negeri Jakarta.

2. Mudlofir, Ali \& Evi Fatimatur Rusydiyah. (2016). Desain Pembelajaran Inovatif Teori dan Praktik. Jakarta: Rajagravindo Persada.

3. Dewi, Fika. (2016). Pengaruh Model Pembelajaran Kooperatif Tipe Numbered Head Together Terhadap Hasil Belajar Siswa Pada Mata Pelajaran Matematika Kelas V Sdn 1 Raman Endra Tahun Pelajaran 2015/2016. FKIP Unila: Bandar Lampung.

4. Sudjana, Nana. (2002). Dasar-dasar Proses Belajar Mengajar. Bandung: PT Remaja Rosdakarya 